\title{
Collaborative Learning: An Effective Approach to Promote Language Development
}

\author{
Nihat Salma ${ }^{1}$ \\ ${ }^{1}$ Department of Languages, Faculty of Education, Tishk International University, Erbil, Iraq \\ Correspondence: Nihat Salma, Tishk International University, Erbil, Iraq. \\ Email: nihat.salma@tiu.edu.iq
}

doi: 10.23918/ijsses.v7i2p57

\begin{abstract}
Collaborative learning is based upon working together on the same task. As learners try to accomplish a task in small groups and search for understanding, they can benefit from each other. The implementation of collaborative learning provides considerable advantages for learners. It gradually contributes to the development of social communication and enhances learners' experiences. The use of this educational approach has an influence on the promotion of student-centered learning which allows learners to construct meaning through interactions with each other. It should be underlined that collaborative learning holds an important place in language learning. Its use in the language classroom can help learners develop communicative competence. This paper attempts to explain the benefits of using collaborative learning in learning settings. In particular, the paper endeavors to demonstrate the contributions of this approach to the development of language learning.
\end{abstract}

Keywords: Collaboration, Cooperation, Communication, Interaction, Language Learning

\section{Introduction}

Collaborative learning has long been of interest owning to its contributions to social communication. While working together learners will be a part of a community and leave individuality and passivity. By means of lending support to each other, they will become effective participants and enhance their experiences.

Compared with individualistic learning, collaborative learning provides higher achievement level for learners. The shift from teacher centeredness to student-centeredness in collaborative learning provides a learning environment in which learners try to construct meaning. Also, in addition to teacher's explanations or presentations, learners search for a product through working in groups. Collaborative language learning has considerable advantages in many aspects for the development of language development. This paper attempts set forth the benefits of collaborative language learning for the enhancement of language promotion.

\section{Benefits of Collaborative Learning}

Collaborative learning is based upon working together on the same task in small groups. It refers to an instruction method in which knowledge is constructed by means of interactions among learners. For that reason, the learner is the major focus of instruction. Through interacting with each other toward a common goal, learners exchange ideas and elaborate their knowledge. Also, learners try to arrive at shared understanding by providing meaningful conversations about the problem and elaborated explanations. 
Collaboration is similar to cooperation; however, in cooperative learning each learner is assigned a portion of the task. Collaborative learning; on the other hand, involves learners working in groups on the same task in order to search for understanding.

Collaborative learning in the classroom has eight basic principles (Jacobs, Power, \& Loh, 2002 as cited in Apple, 2006, p.279):

1. Cooperation as a value

2. Heterogeneous grouping

3. Positive interdependence

4. Individual accountability

5. Simultaneous interaction

6. Equal participation

7. Collaborative skills

8. Group autonomy

The value of cooperation is apparently clear because it provides mutual benefits to participants. The second principle is based on the idea that as participants in a group have diverse backgrounds and experiences, learning opportunities increase which leads to better achievement. Positive interdependence refers to the idea that participants in a group need each other to complete a task. Individual accountability derives from the idea that participants in a group share ideas and knowledge with each other. Simultaneous interaction and equal participation are important principles because in order for the participants to benefit from the task all participants should equally participate in it. Working together will help learners develop their collaborative skills. Yildiz, (2017) argues that the status of participation in the group activities has a vital importance in terms of setting up a close interaction with the group participants; in addition, increases faithfulness or possessiveness in the group. Finally, group work gives opportunities to learners take on responsibilities.

A number of researchers found that collaborative learning approaches triggers critical thinking (Bonk \& Smith, 1998; Thayer-Bacon, 2000; Heyman, 2008). Proponents of collaborative learning emphasize that critical thinking skills allow learners to analyse arguments and make decisions (Paul, 1992; Willingham, 2007). It is also argued that learners with critical thinking skills contribute widely in group tasks (Bailin et al., 1999).

Collaborative learning is also believed to improve learners' metacognition (Martinez, 2006; Schraw et al., 2006; Hennessey, 1999). Metacognition is defined as "the knowledge and control children have over their own thinking and learning activities" (Cross \& Paris, 1998, p. 131). In addition, metacognitive skills allow learners to be aware of their own thinking which can help learners to clarify their beliefs and concepts. According to Bossert (1988) collaborative approaches improve motivation of learners. Gottfried (1990) defines motivation as "enjoyment of school learning characterized by a mastery orientation; curiosity; persistence; task-endogeny; and the learning of challenging, difficult, and novel tasks" (p. 525). According to this perspective working with others enhances individual interest and affect achievement.

During the implementation of collaborative learning several problems can be encountered. While teachers can face problems about creating groups and designing appropriate tasks (Gillies \& Boyle, 2010), learners 
can fail to communicate and collaborate effectively during tasks (Pauli et al., 2008). Moreover, learners learn at different speeds. While some learners learn on their own pace, learning might be insufficient for some students who may need some extra care (Yildiz, 2015). Those who learn fast may have a tendency to take over the group in collaborative learning; for that reason, slow learners may not feel comfortable in the group.

\section{Collaborative Language Learning}

Traditional language learning does not give adequate opportunities to learners to make progress in communication. Leaners' acquiring knowledge comes to the fore in traditional methods; for that reason, negotiation of interaction and meaning does not take place. However, it should be underlined that the development of communicative competence depends on interaction (Mart, 2012). Advocating this idea Jia (2003) stresses that maximizing the needs of learners' communication needs by means of interaction leads to effective language learning. Moreover, interaction encourages learners to negotiate for more input and produce comprehensible output (Crandall, 1999). As learners endeavor to communicate with each other in group settings, they will be provided opportunities to develop their listening comprehension and oral practice (Mart, 2013). It is noteworthy to mention that, communicative competence is necessary for language learning (Mart, 2018).

It is possible to say that collaborative language learning has some common characteristics with communicative language teaching in that they both underline interaction. While learners interact with each other, teacher plays a critical role as a facilitator. In language learning the creation of a relaxed learning setting holds an important place as anxiety may hinder learning. Collaboration language learning has the potential to reduce stress and anxiety and offers a relaxed learning environment. Learners interact with their peers feeling comfortable and confident. Face-to-face interaction with each other reduces their pressure and encourages them for better achievement.

Nunan (1991, p. 1) lists a number of reasons for using collaborative learning:

In language education, teachers, learners, researchers and curriculum specialists can collaborate for a number of reasons. They may wish to experiment with alternative ways of organizing teaching and learning; they may be concerned with promoting a philosophy of cooperation rather than competition; they may wish to create an environment in which learners, teachers and researchers are teaching and learning from each other in an equitable way [...]; or they may wish to experiment with ways of incorporating principles of learner-centredness into their programs.

It is not easy to motivate students in whole period of a lesson; some techniques are essential to be implemented (Tosun \& Yildiz, 2015). Learner-centeredness has the potential to increase motivation in the language classroom. Once learners are motivated, they can have higher achievements (Mart, 2011). That learners cooperate with each other to complete a task, they can enhance their motivation and perform better learning. Moreover, they can benefit from each other. Moreover, commitment and passion learners have in groups will assist students increasing their active participation in the tasks (Yildiz \& Celik, 2017). Another advantage of collaborative learning is its influence on the development of learner autonomy. 


\section{Conclusion}

Collaborative learning is an effective approach to implement in educational settings owing to its advantages to enhance social interaction, student-centeredness and learner autonomy. While learners endeavor to accomplish a task in groups, they exchange ideas and create understanding which help them with better achievement. Collaborative learning is also effectively used in language learning. Interaction leads to the development of communicative competence. In addition, through collaborative learning learners in a stress-free learning environment stand a better chance of developing their language proficiency.

\section{References}

Apple, M.T. (2006). Language Learning Theories and Cooperative Learning Techniques in the EFL Classroom. Doshisha Studies in Language and Culture, 9(2), 277 - 301.

Bailin, S., Case, R., Coombs, J. R., \& Daniels, L. B. (1999). Conceptualizing critical thinking. Journal of Curriculum Studies, 31(3), 285-302.

Bonk, C. J. \& Smith, G. S. (1998). Alternative instructional strategies for creative and critical thinking in the accounting curriculum. Journal of Accounting Education, 16(2), 261-293.

Bossert, S. T. (1988). Cooperative activities in the classroom. Review of Research in Education, 15(1988-1989), 225-250.

Crandall, J. (1999). Cooperative language learning and affective factors. In Arnold, J (Eds.) Affect in language learning. Cambridge University Press. Beijing: Foreign language Teaching and Research Press, 2000.

Cross, D. R. \& Paris, S. G. (1988). Developmental and instructional analyses of children's metacognition and reading comprehension. Journal of Educational Psychology, 80(2), 131-142.

Gillies, R., \& Boyle, M. (2010). Teachers' reflections on cooperative learning: Issues of implementation. Teaching and Teacher Education, 26, 933-940.

Gottfried, A. E. (1990). Academic intrinsic motivation in young elementary school children. Journal of Educational Psychology, 82(3), 525-538.

Hennessey, M. G. (1999, March). Probing the dimensions of metacognition: Implications for conceptual change teaching-learning. Paper presented at the annual meeting of the National Association for Research in Science Teaching, Boston, MA.

Heyman, G. D. (2008). Children's critical thinking when learning from others. Current Directions in Psychological Science, 17(5), 344-347.

Jia, G. (2003). Psychology of foreign language education (2nd edition). Nanning: Guangxi Education Press.

Mart, C.T. (2011). How to sustain students' motivation in a learning environment. ERIC (ED519165).

Mart, C.T. (2012). Developing speaking skills through reading. International Journal of English Linguistics, 2 (6), 91-96.

Mart, C.T. (2013). The direct method: A good start to teach oral language. International Journal of Academic Research in Business and Social Sciences, 3(11), 182-184.

Mart, C.T. (2018). From communicative competence to language development. International Journal of English Linguistics, 8(2), 163-167.

Martinez, M. E. (2006). What is metacognition? Phi Delta Kappan, 87(9), 696-699.

Nunan, D. (1991). Language teaching methodology. Hemel Hempstead: Prentice Hall.

Paul, R. W. (1992). Critical thinking: What, why, and how? New Directions for Community Colleges, 1992(77), 3-24. 
Pauli, R., Mohiyeddini, C., Bray, D., Michie, F., \& Street, B. (2008). Individual differences in negative group work experiences in collaborative student learning. Educational Psychology, 28, 47-58.

Schraw, G., Crippen, K. J., \& Hartley, K. (2006). Promoting self-regulation in science education: Metacognition as part of a broader perspective on learning. Research in Science Education, 36, 111-139.

Thayer-Bacon, B. J. (2000). Transforming critical thinking: Thinking constructively. New York: Teachers College Press.

Tosun, M., \& Yildiz, Y. (2015). Extracurricular Activities as Warm-Ups in Language Teaching. International Journal of Social Sciences \& Educational Studies, 2(1), 62-64.

Willingham, D. T. (2007). Critical thinking: Why is it so hard to teach? American Educator, $31(2), 8-19$.

Willingham, D. T. (2007). Critical thinking: Why is it so hard to teach? American Educator, $31(2), 8-19$.

Yildiz, Y. (2015). Time spent in target language-oriented extracurricular activities and foreign language students' satisfaction. In 5th International Research Conference on Education, Tbilisi, Georgia (pp. 478-482).

Yildiz, Y., \& Celik, B. (2017). Commitment to the teaching profession. International Journal of Social Sciences \& Educational Studies, 4(2), 93-97.

Yildiz, Y. (2017). Components of Commitment to the Teaching Profession. International Journal of Social Sciences \& Educational Studies, 4(2), 115-122. 